\title{
FORMOVANIE ÚSTAVNÉHO POSTAVENIA PREZIDENTA SLOVENSKEJ REPUBLIKY (PRIBLIŽOVANIE ALEBO VZĎALOVANIE SA MODELU Z PRVEJ ČESKOSLOVENSKEJ REPUBLIKY)*
}

\author{
L'UBOR CIBULKA, MAREK DOMIN
}

\begin{abstract}
Forming the constitutional position of the President of the Slovak Republic (Approaching the model of the first Czechoslovak Republic or retreating from it)

This paper is dealing with a brief analysis of the formation of the constitutional status of the President of the Slovak Republic during the constitutional development of the Slovak Republic since 1993 to the present. The attention is paid to five issues, which in their entirety have formed the constitutional status of the head of the Slovak Republic. These issues are election of the President, powers of the President and the way in which these powers are performed, as well as the President's responsibility for the performance of the office and deputizing for the presidential office. The analysis is completed on the occasion of the centennial anniversary of the Czechoslovak Republic and the first introduction of the institute of the President as Head of State by short comparison of the formation of the constitutional status of the President of the Slovak Republic with the first-Republic presidential model.
\end{abstract}

Keywords: countersignature; deputizing for the president; election of the president; parliamentary form of government; powers of the president; president; responsibility of the president

Kl’účové slová: kontrasignácia; parlamentná forma vlády; právomoci prezidenta; prezident; vol'ba prezidenta; zastupovanie prezidenta; zodpovednost' prezidenta

DOI: $10.14712 / 23366478.2018 .17$

\section{ÚVOD}

V r. 2018 si pripomíname už sté výročie vzniku (prvej) Československej republiky. Rok 1918, teda rok vzniku spoločného československého štátu, bol nepochybným zlomom nie len v dlhotrvajúcej snahe Slovákov o vytvorenie vlastného štátu, ale aj v ústavnoprávnom vývoji na našom území. Vznik Československej republiky totiž, okrem iného, do československého a teda aj do slovenského politického a právne-

\footnotetext{
* Tento článok bol vypracovaný v rámci programu PROGRES Q04. Autori sú pracovníkmi katedry ústavného práva Právnické fakulty Univerzity Komenského v Bratislave.
} 
ho prostredia po prvý raz zavádza inštitút prezidenta republiky ako individuálnej hlavy štátu. Na túto tradíciu nadviazal aj slovenský ústavodarca, ked’že inštitút prezidenta ako individuálnej hlavy štátu zakotvil aj do Ústavy Slovenskej republiky (d’alej aj len „Ústava SR“). ${ }^{1}$

Ústavné postavenie prezidenta republiky ako hlavy Československej republiky tak, ako bolo vyjadrené v Ústavnej listine Československej republiky (d'alej aj len „Ústavná listina ČSR“), ${ }^{2}$ môžeme stotožnit' s postavením hlavy štátu typickým pre ústavné systémy vychádzajúce z parlamentnej formy vlády. Išlo o hlavu štátu volenú parlamentom (oboma parlamentnými komorami), ${ }^{3}$ ktorá $\mathrm{v}$ štáte tvorila, spolu s vládou, moc vládnu a výkonnú. Dominantná rola v rámci výkonnej moci však patrila vláde, čo z ústavnoformálneho hl'adiska potvrdzovalo aj to, že vláde patrila všetka vládna a výkonná moc, ktorú Ústavná listina ČSR alebo zákony nezverili prezidentovi republiky. ${ }^{4}$ Dalším rysom typickým pre parlamentnú formu vlády bolo to, že akýkol’vek prezidentov akt moci vládnej alebo výkonnej vyžadoval k svojej platnosti kontrasignáciu zodpovedného člena vlády. ${ }^{5}$ Samozrejme, z ústavnopolitického hl'adiska nemožno úplne opomenút' ani osobu prezidenta a jeho politickú aktivitu, ktoré do značnej miery praktické postavenie úradu prezidenta ovplyvňovali. Osobitne to platilo najmä o prvom prezidentovi Československej republiky, ktorým bol Tomáš Garrigue Masaryk. ${ }^{6}$ Fungovanie ústavného systému Československej republiky bolo však v praxi do nemalej miery ovplyvnené aj mimoparlamentným a mimoústavným mocenským centrom, tzv. Pätkou. ${ }^{7}$

Ciel'om tohto príspevku je, pri príležitosti stého výročia prvého zavedenia inštitútu prezidenta republiky ako hlavy štátu, stručne zhodnotit' formovanie ústavného postavenia prezidenta Slovenskej republiky (d’alej aj len „prezident“ alebo „prezident SR“), a to osobitne $\mathrm{v}$ kontexte toho, či možno $\mathrm{v}$ jeho prípade hovorit' o približovaní sa alebo o vzd'al'ovaní sa prvorepublikovému modelu prezidenta republiky. Analýza formovania ústavného postavenia prezidenta SR bude rozdelená do piatich vecných častí, ktoré nepochybne vo svojom súhrne predstavujú fundamentálny základ ústavného postavenia každej hlavy štátu. V prvej časti príspevku sa budeme venovat' otázke (1) ustanovovania prezidenta SR do jeho funkcie, následne jeho (2) právomociam a (3) spôsobu výkonu týchto právomoci. Štvrtá čast' príspevku bude zameraná na (4) zodpovednost' prezidenta SR a piata čast' (5) na zastupovanie prezidenta. V každej z uvedených častí sa pokúsime aj o stručnú komparáciu s modelom prezidenta z prvej Československej republiky. Záver príspevku bude venovaný stručnému komplexnému zhrnutiu a zodpovedaniu otázky

\footnotetext{
Ústava Slovenskej republiky č. 460/1992 Zb. v znení neskorších predpisov.

Zákon č. 121/1920 Sb., ktorým sa uvádza Ústavná listina Československej republiky.

Porovnaj § 56 a nasl. Ústavnej listiny ČSR.

Porovnaj § 64 ods. 2 Ústavnej listiny ČSR.

Porovnaj § 68 Ústavnej listiny ČSR.

Tomáš Garrigue Masaryk vykonával úrad prezidenta republiky od r. 1918 až do r. 1935. Za prezidenta bol po prvý raz zvolený ešte revolučným Národným zhromaždením v r. 1918. Po prijatí Ústavnej listiny ČSR bol za prezidenta zvolený ešte tri razy, a to v r. 1920, 1927 a 1934.

7 Išlo o predstavitel'ov piatich najvýznamnejších politických strán. Porovnaj napr. VODIČKA, K. CABADA, L.: Politický systém České republiky. Historie a současnost. Praha: Portál, 2011, s. 40. Porovnaj aj DOBRÍK, L'. Koaličná rada v ústavnom systéme Slovenskej republiky (historickoprávne aspekty). Štát a právo, 2014, č. 2, s. 215 a nasl.
} 
naznačenej už v podnadpise príspevku, a teda, či sa ústavné postavenie prezidenta SR po jeho takmer dvadsat'pät'ročnom vývoji približuje alebo vzd'al'uje prvorepublikovému modelu. ${ }^{8}$

\section{USTANOVOVANIE PREZIDENTA DO FUNKCIE}

Formovanie ústavného postavenia prezidenta SR nepochybne bolo a je ovplyvnené aj spôsobom jeho ustanovovania do funkcie. Skutočnost', kto prezidenta do funkcie ustanovuje, teda to, od koho prezident odvodzuje svoju legitimitu, totiž môže mat' nezanedbatel'ný vplyv nie len na praktický výkon jeho právomocí, ale môže predstavovat' aj potenciálnu platformu pre ich rozšírenie. Už samotné pomenovanie „,prezident“ zretel’ne prezrádza, že ide o hlavu štátu ustanovovanú do funkcie vol'bou. Zásadným vývojom však prešiel spôsob vol'by prezidenta SR.

Ústava SR vo svojom pôvodnom znení zverovala právomoc volit’ prezidenta najvyššiemu zastupitel'skému orgánu, teda Národnej rade Slovenskej republiky (d’alej aj len „Národná rada“ alebo „NR SR“). ${ }^{9}$ Vol'ba hlavy štátu najvyšším zastupitel'ským orgánom zodpovedala zvyklostiam v podmienkach klasickej parlamentnej forme vlády. ${ }^{10}$ Národná rada $v$ zmysle pôvodnej ústavnej úpravy volila prezidenta tajným hlasovaním na obdobie piatich rokov, pričom na zvolenie sa vyžadovala trojpätinová väčšina hlasov všetkých poslancov. Podrobnosti o spôsobe vol'by Národná rada upravila svojim uznesením. K podmienkam pasívneho voleného práva, t. j. k podmienkam zvolitel'nosti, patrilo štátne občianstvo SR, vek 35 rokov a existencia aktívneho volebného práva. ${ }^{11}$ Tá istá osoba mohla byt' za prezidenta zvolená najviac dva krát po sebe. Ak žiadny z kandidátov potrebnú väčšinu hlasov nezískal, konala sa do 14 dní opakovaná vol’ba. Ak ani v opakovanej vol'be žiadny z kandidátov nezískal potrebnú väčšinu, konali sa nové vol'by. Ústava SR teda neobsahovala žiadne liberalizačné podmienky pre prípad, že sa nepodarí žiadnemu kandidátovi získat' potrebnú trojpätinovú väčšinu. ${ }^{12}$

Stručne popísané prísne podmienky zvolenia prezidenta predstavovali, osobitne v podmienkach zložitej politickej kultúry, ,časovanú nálož“ a vytvárali možnost’ vzniku ústavnej krízy. Vývoj po uplynutí volebného obdobia prvého prezidenta to aj potvrdil. ${ }^{13}$ Je nesporné, že v podmienkach parlamentnej formy vlády je vhodné, aby legitimita hlavy štátu bola založená na čo najväčšom konsenze poslancov parlamentu,

8 K vývoju postavenia prezidenta SR porovnaj napr. aj DRGONEC, J.: Ústava Slovenskej republiky. Teória a prax. Bratislava: C. H. Beck, 2015, s. 1170 a nasl. Zo staršej literatúry pozri napr. aj OROSZ, L. - ŠIMUNIČOVÁ, K.: Prezident v ústavnom systéme Slovenskej republiky. Bratislava: Veda, 1998. Pre všeobecnejší pohl'ad na postavenie hlavy štátu pozri napr. TÓTHOVÁ, M.: Hlava štátu v systéme del'by moci. Košice: UPŠ, 2015.

9 Porovnaj čl. 101 ods. 2 Ústavy SR v pôvodnom znení.

10 Porovnaj napr. BLAHOŽ, J. - BALAŠ, V. - KLÍMA, K.: Srovnávací ústavní právo. Praha: Wolters Kluwer, 2011, s. 110 .

11 Porovnaj čl. 103 ods. 1 Ústavy SR v pôvodnom znení.

12 K takýmto liberalizačným podmienkam vo všeobecnosti možno zaradit’ napr. zníženie požadovanej väčšiny hlasov poslancov či možnost' rozpustenia parlamentu z dôvodu neschopnosti zvolit' prezidenta.

13 Volebné obdobie prvého prezidenta SR Michala Kováča uplynulo 2. marca 1998. Druhý prezident SR, Rudolf Schuster, bol zvolený až 29. mája 1999. 
no súčasne by však mali byt' vytvorené podmienky na zvolenie hlavy štátu v prijatel'nej fáze volebného procesu. Neschopnost' NR SR zvolit' prezidenta, ako aj rozloženie a výrazná polarizácia politických síl vyvolali tlak na zmenu spôsobu vol'by hlavy štátu. Požiadavku na zmenu spôsobu vol'by, konkrétne na priamu vol'by prezidenta, vyjadrili aj občania petíciou žiadajúcou vyhlásenie referenda, ktoré však bolo napokon zmarené. ${ }^{14}$ Uvedená situácia po vol'bách do NR SR v r. 1998, ktoré priniesli zásadnú zmenu v politickej orientácii SR, vyústila v novelu Ústavy SR, a to v podobe ústavného zákona č. 9/1999 Z. z. ${ }^{15}$ Predmetný ústavný zákon, ktorý predstavoval druhú priamu novelu Ústavy SR, tak nakoniec zaviedol dlho čakávanú priamu vol'bu prezidenta. ${ }^{16}$ Okrem zmeny spôsobu vol'by hlavy štátu táto novela zaviedla do ústavného systému aj inštitút l’udového hlasovania o odvolaní prezidenta, ako aj úpravu niektorých prezidentských právomocí. Podrobnosti o priamej vol'be prezidenta upravil osobitný vykonávací zákon. ${ }^{17}$

Pokial ide o samotné novozavedené podmienky zvolenia, tie boli taktiež nastavené pomerne prísne. Podl’a čl. 101 ods. 4 Ústavy SR v znení ústavného zákona č. 9/1999 Z. z. sa na zvolenie prezidenta vyžadovalo a vyžaduje získanie nadpolovičnej väčšiny platných hlasov oprávnených voličov. Táto norma sa konzistentne vykladá tak, že na zvolenie je potrebný zisk nadpolovičnej väčšiny hlasov všetkých oprávnených voličov. ${ }^{18}$ Takto prísne nastavené podmienky však mali svoj zmysel, ak argumentom $\mathrm{v}$ prospech zavedenia priamej vol'by hlavy štátu bolo získanie silnej legitimity od občanov. Ak žiadny z kandidátov nezíska potrebnú väčšinu, koná sa druhé kolo volieb, do ktorého postupujú dvaja kandidáti s najvyšším počtom hlasov. V druhom kole volieb sú podmienky miernejšie a sú tak vytvorené ústavnoprávne podmienky preto, aby prezident bol zvolený. V druhom kole je za prezidenta zvolený ten kandidát, ktorý získal najväčší počet platných hlasov zúčastnených voličov. Čo sa týka d'alších podrobností novej úpravy volieb prezidenta, v porovnaní s pôvodnou úpravou sa zvýšila veková hranica pre pasívne volebné právo z 35 na 40 rokov. Právo navrhovat' kandidátov ústavný

14 Referendum za zmarené vyhlásila Ústredná komisia pre referendum, a to v dôsledku konania Ministerstva vnútra SR, ktoré nezabezpečilo tlač a distribúciu hlasovacích lístkov so všetkými štyrmi otázkami. Súčast’ou hlasovacích lístkov, v časti obcí, nebola otázka týkajúca sa priamej vol’by prezidenta. Ministerstvo vnútra svoj postup odôvodňovalo uznesením Ústavného súdu Slovenskej republiky, sp. zn. II. ÚS 31/97, ktoré bolo vydané len dva dni pred konaním referenda.

15 Ústavný zákon č. 9/1999 Z. z., ktorým sa mení a dopĺn̆a Ústava Slovenskej republiky č. 460/1992 Zb. v znení ústavného zákona č. 244/1998 Z. z.

16 Porovnaj čl. 101 ods. 2 až 10 a čl. 103 Ústavy SR v znení ústavného zákona č. 9/1999 Z. z.

17 Pôvodne išlo o zákon č. 46/1999 Z. z. o spôsobe vol'by prezidenta Slovenskej republiky, o l’udovom hlasovaní o jeho odvolaní a o doplnení niektorých d’alších zákonov. Tento zákon bol s účinnost'ou od $\mathrm{r}$. 2015 nahradený zákonom č. 180/2014 Z. z. o podmienkach výkonu volebného práva a o zmene a doplnení niektorých zákonov.

18 Ak však slovenskú ústavnú úpravu podmienok zvolenia prezidenta v prvom kole porovnáme s českou ústavnou a zákonnou úpravou, záver o nutnosti získania hlasov nadpolovičnej väčšiny hlasov všetkých voličov, teda nie len tých zúčastnených, nemusí byt' až tak jednoznačný. Pre podrobnosti o možnom alternatívnom výklade porovnaj napr. DOMIN, M.: Zvolenie prezidenta v prvom kole. Alebo o tom, že ak dvaja robia to isté, nemusí to byt' to isté. Projustice, 2014, roč. 3, 17. marec 2014. Dostupné na http://www .projustice.sk/ustavne-pravo/zvolenie-prezidenta-v-prvom-kole 
zákon priznal dvom subjektom, a to skupine najmenej 15 poslancov NR SR a skupine najmenej 15000 občanov, v druhom prípade prostredníctvom petície. ${ }^{19}$

V porovnaní s pôvodnou ústavnou úpravou sa ústavným zákonom č. 9/1999 Z. z. spresnil aj začiatok plynutia funkčného obdobia prezidenta. Pôvodná dikcia Ústavy SR totiž neobsahovala úpravu začiatku a konca jeho plynutia a súčasne rozoznávala pojmy „volebné obdobie“ a „funkčné obdobie“. Ešte pred prijatím predmetnej ústavnej novely Ústavný súd Slovenskej republiky (d’alej aj len „Ústavný súd“ alebo „ÚS SR“) vo svojom výkladovom rozhodnutí uviedol, že volebné obdobie a funkčné obdobie je totožné a začína plynút' odo dňa zloženia slubu a končí uplynutím piatich rokov od jeho zloženia. ${ }^{20}$ Ústavný zákon č. 9/1999 Z. z. vo väzbe na uvedené rozhodnutie zakotvil v čl. 101 ods. 7 Ústavy SR, že zvolený kandidát sa ujíma funkcie prezidenta zložením sl’ubu, ktorý má konštitutívnu povahu. Pôvodne prezident skladal sl’ub pred NR SR do rúk jej predsedu, po zavedení priamej vol'by prezidenta sa tento skladá slúb pred NR SR do rúk predsedu ÚS SR.

So zmenou spôsobu vol'by prezidenta sa nepochybne spája otázka, či exitovala spoločenská či ústavnoprávna nevyhnutnost' na zavedenie jeho priamej vol'by, a to osobitne v podmienkach ústavného systému stojaceho na princípoch parlamentnej formy vlády. Súčasné trendy naznačujú, že priama vol'ba hlavy štátu nemusí byt' v úplnom rozpore s princípmi parlamentarizmu. ${ }^{21}$ Súčast’ou argumentácie o nutnosti zavedenia priamej vol'by bolo tvrdenie, že priama vol'ba posilní legitimitu prezidenta, ked’že mandát získa od občanov (voličov), pričom táto legitimita bude posilnená zavedením prísnych podmienok zvolenia. Argumentovalo sa aj tým, že postavenie prezidenta bude výraznejšie i bez toho, aby sa menili jeho právomocí. Ďalším argumentom bol názor, že priama vol'ba občanmi vytvorí i jasný vzt’ah hlavy štátu voči občanom, že sa tým povaha jeho mandátu sa stane ovel'a jasnejšou a zrozumitel'nejšou. Za najdôležitejší prínos sa považovala väčšia kontrola ústavného systému štátu občanmi, pretože v ňom budú pôsobit’ dva nimi priamo volené orgány, a to prezident a NR SR. Zavedenie priamej vol'by prezidenta bolo však predovšetkým racionálnym politickým rozhodnutím. V tejto súvislosti možno jednoznačne súhlasit's L. Kopečkom, ktorý uviedol, že ,,zavedenie priamej vol'by prezidenta občanmi nesledovalo ciel' posilnenia postavenia slovenského prezidenta, ale riešenie existujúceho ústavného problému Podstatou tohto problému bola nefunkčnost’ pôvodného mechanizmu vol'by prezidenta “.22 Zrejme možno súhlasit’ aj s názorom, ako vyplynie aj z časti príspevku venujúceho sa právomociam prezidenta, že priama vol'ba prezidenta SR sa výraznejšie nepremietla do jeho právomocí, resp. že ústavodarca neuvažoval o komplexnom naplnení legitimity prezidenta posilnenej v dôsledku priamej

19 Pre podrobnejšiu analýzu volieb prezidenta SR pozri napr. DOMIN, M.: Volebné právo a volebné systémy. Bratislava: Wolters Kluwer, 2017, s. 289 a nasl.; zo zahraničnej literatúry napr. SKOTNICKI, K.: Prawo vyborcze na urzad prezydenta w Slowacii. In: GRABOWSKA, S. - GRABOWSKI, R. (eds.): Prawo wyborcze na urzad prezydenta w państwach europejskich. Warszawa: Oficyna a Wolters Kluwer, 2007, s. 176 a nasl.

20 Porovnaj uznesenie ÚS SR z 10. decembra 1997, sp. zn. II. ÚS 65/97.

21 Porovnaj napr. SUCHÁNEK, R. - JIRÁSKOVÁ. V.: Ústava České republiky v praxi: 15 let platnosti základního zákona. Praha: Leges, 2009, s. 173.

22 KOPEČEK, L'.: Prezident v politickém systému Slovenska - nelehké hledání fungujícího modelu. In: NOVÁK, M. - BRUNCLÍK, M. (eds.): Postaveni hlavy státu v parlamentních a poloprezidentských režimech. Česká republika v komparativní perspektivě. Praha: Dokořán, 2008, s. 201. 
vol’by. Priama vol'ba hlavy štátu zavedená ústavným zákonom č. 9/1999 Z. z. platí dodnes. Aj napriek možným polemikám ohl'adom dôvodov jej zavedenia totiž v súčasnom politickom a ani ústavnoprávnom diskurze neexistuje výrazný záujem na návrat spät' k parlamentnej vol'be. ${ }^{23}$

Ak stručne popísaný vývoj spôsobu vol'by prezidenta SR porovnáme s prezidentom republiky z dôb prvej Československej republiky (d'alej aj len „,prezident ČSR“), možno jednoznačne identifikovat' vzd'al'ovanie sa pôvodne vel'mi podobného slovenského modelu tomu prvorepublikovému. Prezident ČSR bol totiž volený Národným zhromaždením, in concreto na spoločnej schôdzi Poslaneckej snemovne a Senátu. Podobné boli aj podmienky pasívneho voleného práva, ked' za prezidenta ČSR mohol byt' zvolený len československý štátny občan volitel'ný o Poslaneckej snemovne, ktorý dosiahol vek 35 rokov. Negatívnou podmienkou pasívneho volebného práva bolo taktiež to, že dotknutý kandidát nevykonával funkciu prezidenta v dvoch predchádzajúcich po sebe nasledujúcich obdobiach. ${ }^{24}$ Ak nepočítame dôsledok existencie dvojkomorového parlamentu, tak jednými podstatnejšími rozdielmi medzi prvorepublikovým a pôvodným slovenským modelom vol'by prezidenta bolo jednak dlhšie volebné obdobie (sedem rokov v prípade ČSR a pät' v prípade SR), ako aj podrobnejšia a dôsledkom toho aj potenciálne funkčnejšia ústavná úprava parlamentnej vol'by. Tá v podmienkach ČSR obsahovala aj liberalizačné podmienky. 25

\section{PRÁVOMOCI PREZIDENTA}

Ďalšou otázkou, ktorá podstatným spôsobom formuje postavenie každej hlavy štátu, nie len prezidenta SR, sú právomoci, ktoré ústavný systém hlave štátu zveruje. V nasledujúcej časti sa budeme stručne venovat’ tomu, aké právomoci Ústava SR prezidentovi SR zveruje a zverovala.

Rovnako ako v otázke ustanovovania prezidenta do funkcie, tak aj v otázke prezidentských právomocí prešla Ústava SR nezanedbatel'ným vývojom. V jej pôvodnom texte boli právomoci prezidenta SR vo viacerých otázkach vymedzené širšie, ako je to obvyklé v klasických modeloch parlamentnej formy vlády. Osobitne to platilo vo vzt’ahu k vláde Slovenskej republiky (d’alej aj len „vláda“ alebo „vláda SR“). ${ }^{26}$ Pokial” ide o právomoci prezidenta SR de constitutione lata, tie sú predovšetkým predmetom čl. 102 ods. 1. Výpočet právomocí uvedený v citovanom ustanovení však nemožno označit' za taxatívny. Ústava SR totiž prezidentské právomoci upravuje aj na iných

23 Pre viac podrobností o procese a dôvodoch zavedenia priamej vol'by prezidenta SR pozri napr. CIBULKA, L.: Vývoj prezidenta v ústavnom systéme Slovenskej republiky (v kontexte zmien Ústavy Slovenskej republiky). Actas Facultatis Iuridicae Universitatis Comenianae, 2012, roč. 31, č. 1, s. 82-122.

24 Toto obmedzenie sa však v zmysle $\S 58$ ods. 4 Ústavnej listiny ČSR nevzt’ahovalo na prvého prezidenta ČSR, ktorým bol Tomáš Garrigue Masaryk. Ten bol po prijatí Ústavnej listiny ČSR zvolený až tri razy po sebe.

25 Pre podrobnosti o vol'be prezidenta ČSR pozri napr. WEYR, F. Československé právo ústavní. Praha: Melantrich, 1937, s. 181 a nasl.

26 Porovnaj OROSZ, L. - ŠIMUNIČOVÁ, K.: Prezident v ústavnom systéme Slovenskej republiky. Bratislava: Veda, 1998, s. 71. 
miestach. V súvislosti s ústavou úpravou právomocí prezidenta je taktiež potrebné dodat', že Ústava SR ich rozšírenie „bežným“ zákonom nepripúšt’a. Zákon síce môže upravit' podrobnosti o výkone právomocí prezidenta, nie však mu priznat' d’alšie. ${ }^{27}$

Počet právomocí, ktoré Ústava SR prezidentovi zveruje, je relatívne rozsiahly. Z dôvodu väčšej prehl'adnosti ich z vecného hl'adiska môžeme rozdelit' napríklad do nasledujúcich skupín:

(1) právomoci vo vzt’ahu $\mathrm{k}$ zahraničiu a bezpečnosti SR;

(2) právomoci vo vzt'ahu k NR SR a zákonodarnej moci;

(3) právomoci vo vzt’ahu $\mathrm{k}$ vláde SR;

(4) právomoci vo vzt’ahu k súdnej moci;

(5) d’alšie kreačné právomoci a

(6) d’alšie tradičné prerogatívy hlavy štátu.

\section{Ad 1)}

Prezident SR v zmysle všeobecnej ústavnej charakteristiky reprezentuje SR navonok. ${ }^{28}$ Vzhl’adom na uvedené majú nepochybne dôležitý význam tie z právomocí prezidenta, ktoré mu umožňujú SR navonok reprezentovat'. K právomociam prezidenta, ktoré môžeme zaradit' do skupiny právomocí vo vzt’ahu k zahraničiu a bezpečnosti SR, konkrétne patrí: (1) zastupovanie SR navonok; (2) dojednávanie a ratifikácia medzinárodných zmlúv; (3) prijímanie, poverovanie a odvolávanie vedúcich diplomatických misií; (4) možnost’ obrátit' sa na ÚS SR s návrhom na posúdenie ústavnosti dojednanej medzinárodnej zmluvy; (5) vypovedanie vojny a uzatváranie mieru, ako aj vyhlásenie vojnového stavu a výnimočného stavu a vyhlásenie ich skončenia; (6) nariad'ovanie mobilizácie ozbrojených síl SR a (7) vymenúvanie a povyšovanie generálov. Posledné z uvedených právomocí konkretizujú všeobecnú ústavnú normu, podla ktorej je prezident hlavným velitel'om ozbrojených síl. ${ }^{29}$

Právomoci prezidenta, ktoré sme zaradili do prvej skupiny, síce prešli určitými zmenami, no tie nemožno považovat' za zásadné. Výraznejšie zmeny priniesol ústavný zákon č. 90/2001 Z. z., ${ }^{30}$ ktorý doplnil kreačnú právomoc prezidenta vo vzt’ahu k vedúcim diplomatických misií aj o výslovnú úpravu možnosti ich odvolania. ${ }^{31}$ Rovnaký ústavný zákon prezidentovi taktiež zveril aj oprávnenie obrátit' sa na ÚS SR so žiadost'ou o posúdenie ústavnosti dojednanej medzinárodnej zmluvy. Takáto právomoc v pôvodnom texte Ústavy SR absentovala.

\section{Ad 2)}

Prezidentovi aj napriek skutočnosti, že nejde o orgán zákonodarnej moci, Ústava SR zverila dôležité právomoci aj vo vzt’ahu k NR SR ako jedinému zákonodarnému orgánu. Prezidentovi taktiež patrí právomoc vyhlasovat' referendum, ktorú, vzhl’adom na

27 Porovnaj čl. 102 ods. 4 Ústavy SR.

28 Porovnaj čl. 101 ods. 1 Ústavy SR.

29 Porovnaj čl. 102 ods. 1 písm. k) Ústavy SR.

30 Ústavný zákon č. 90/2001 Z. z., ktorým sa mení a dopíňa Ústava Slovenskej republiky v znení neskorších predpisov.

31 V zmysle čl. 102 písm. b) Ústavy SR v pôvodnom znení však išlo o „vyslancov“, nie o vedúcich diplomatických misií. 
skutočnost', že Ústava SR celoštátne referendum považuje za osobitný spôsob výkonu zákonodarnej moci, ${ }^{32}$ možno zaradit' do rovnakej skupiny právomocí. K právomociam prezidenta vo vzt'ahu k NR SR patrí: (1) zvolávanie ustanovujúcej schôdze NR SR; (2) možnost' alebo povinnost' rozpustit' NR SR, a to v závislosti od splnenia d'alších Ústavou SR predpokladaných podmienok; ${ }^{33}$ (3) podpisovanie zákonov a (4) možnost' vrátit' zákon s pripomienkami spät' do NR SR. V prípade poslednej z uvedených právomocí ide o tzv. právo suspenzívneho (relatívneho) veta, ked’že NR SR môže nesúhlas prezidenta so schváleným zákonom takpovediac „,prelomit““. Do skupiny prezidentských právomocí smerujúcich k Národnej rade možno nepochybne zaradit' aj (5) podávanie správ o stave SR a správ o závažných politických otázkach. ${ }^{34}$

Počas takmer dvadsat'pät'ročnej platnosti Ústavy SR sa jej viaceré novelizácie dotkli aj právomocí prezidenta vo vzt’ahu k NR SR. Z hl'adiska hodnotenia týchto zmien môžeme hovorit' skôr o ich spresnení a doplnení, než o zásadných zmenách. Výraznejšími zmenami prešla napr. právomoc prezidenta rozpustit' NR SR. Obsah tejto právomoci vychádza z koncepcie tzv. neutrálneho postavenia prezidenta ako hlavy štátu, ktorý by mal pôsobit' ako arbiter v ústavných sporoch predovšetkým medzi NR SR a vládou SR. Pôvodný text Ústavy SR dával prezidentovi oprávnenia tohto druhu len v zúženom rozsahu, a to tak z hl'adiska obsahu, ako aj z hl'adiska času využitel'nosti. Podl'a pôvodného znenia čl. 102 ods. 1 písm. d) Ústavy SR prezident mohol rozpustit’ NR SR len v prípade, ak tri razy do šiestich mesiacov po vol’bách nedôjde k schváleniu programového vyhlásenia vlády. Prezident bol povinný súčasne vypočut' si stanovisko predsedu NR SR. Po uplynutí šiestich mesiacov uvedené arbiterské oprávnenie už nebolo možné uplatnit', čo potenciálne otváralo priestor pre vznik ústavnej krízy. Posun znamenalo prijatie ústavného zákona č. 90/2001 Z. z. Podl'a nového znenia Ústavy SR prezident môže Národnú radu rozpustit' v prípade, ak (1) NR SR v lehote šiestich mesiacov od vymenovania vlády neschválila jej programové vyhlásenie; (2) ak sa NR SR neuzniesla do troch mesiacov o vládnom návrhu zákona, s ktorým vláda spojila hlasovanie o vyslovenie dôvery; (3) ak NR SR nebola dlhšie ako tri mesiace spôsobilá uznášat' sa, hoci jej zasadanie nebolo prerušené a hoci bola v tom čase opakovane zvolávaná na schôdzu, alebo (4) ak bolo zasadanie NR SR prerušené na dlhší čas ako dovol'uje ústava. ${ }^{35}$ Toto oprávnenie prezident nemôže uplatnit' počas posledných šiestich mesiacov svojho volebného obdobia, čo sleduje ciel' zamedzit' potenciálnemu zneužitiu tohto inštitútu na politické zápasy v predvolebnom období. Prezident Národnú radu nemôže rozpustit' ani v čase vojny, vojnového stavu alebo výnimočného stavu.

Podstatnými zmenami prešla aj prezidentská právomoc vrátit' Národnej rade zákon s pripomienkami. De constitutione lata má prezident právo vrátit' do NR SR zákon

32 Toto tvrdenie, ktoré vyplýva aj z formálneho zaradenia inštitútu referenda do piatej hlavy Ústavy SR nazvanej „Zákonodarná moc“, v minulosti potvrdil aj Ústavný súd. Porovnaj uznesenie ÚS SR z 21. mája 1997, sp. zn. II. ÚS 31/97.

33 Podmienky, za ktorých prezident môže alebo naopak musí NR SR rozpustit', taxatívne upravuje čl. 102 ods. 1 písm. e) Ústavy SR.

34 Viac k právomoci prezidenta SR podávat' správy o stave SR a správy o závažných politických otázkach napr. v DOMIN, M.: Správa o stave republiky ako prezidentská právomoc. Justičná revue, 2014, roč. 66, č. 8-9, s. 1049-1066.

35 Porovnaj čl. 102 ods. 1 písm. e) Ústavy SR. 
s pripomienkami v lehote 15 od jeho doručenia. Podl'a pôvodného znenia relevantnej časti Ústavy SR mohol prezident vrátit’ nie len „bežné“ zákony ale dokonca aj ústavné zákony. Odlišný bol taktiež aj spôsob ústavnej formulácie lehoty na vrátenie. Prezident mohol zákon vrátit' v lehote do 15 dní od jeho schválenia v NR SR. Ďalšou odlišnost’ou pôvodnej ústavnej úpravy bolo aj to, že prezident mal povinnost' zákon Národnej rade vrátit' v prípade, pokial' ho o to požiadala vláda. Pôvodná ústavná úprava nastol'ovala viaceré otázky. Na prvom mieste to bola otázka, či je vôbec legitímne, aby prezident mal možnost' vrátit' ústavný zákon, a to so zretel'om na princíp suverenity l'udu a so zretel'om na princípy parlamentnej formy vlády. Problematickou bola i lehota na vrátenie zákona. Pôvodne formulovaná lehota umožňovala manipulovat' so schváleným zákonom z hl'adiska času jeho predloženia prezidentovi na podpis a tým prezidentovi potenciálne čas na rozhodovanie o eventuálnom vetovaní zákona skrátit'. Nejasnosti sa týkali aj určenia konca lehoty, ak pätnásty deň pripadol na deň pracovného vol'na. Právomoc prezidenta vrátit' Národnej rade ústavný zákon, ako aj právomoc vlády prezidenta o vrátenie zákona požiadat', napokon „vzal“ ústavný zákon č. 9/1999 Z. z. ${ }^{36}$

\section{Ad 3)}

Ako sme už naznačili, ústavný systém SR nepochybne vychádza zo základných princípov parlamentnej formy vlády. Nevyhnutným predpokladom pre zavíšenie procesu kreácie vlády je totiž dôvera zo strany parlamentu. ${ }^{37} \mathrm{~V}$ prostredí parlamentnej formy vlády sú preto osobitne dôležité právomoci hlavy štátu vo vzt'ahu $\mathrm{k}$ vláde. Inak tomu nie je ani v prípade vlády SR, ktorú Ústava SR charakterizuje ako vrcholný orgán výkonnej moci. $^{38}$

Právomoci prezidenta vo vzt’ahu k vláde majú predovšetkým kreačný charakter. Je to totiž práve prezident, ktorý po vol'bách do NR SR zohráva dôležitú úlohu pri kreácii vlády. Prezident má v tejto súvislosti nasledujúce právomoci: (1) vymenúvanie predsedu vlády SR; (2) vymenúvanie ostatných členov vlády a ich poverovanie riadením ministerstiev, a to na návrh predsedu vlády a (3) odvolávanie predsedu a ostatných členov vlády, avšak len v prípade, ak nastane Ústavou SR predpokladaná skutočnost'. Za takúto skutočnost' je potrebné považovat' najmä vyslovenie nedôvery vláde zo strany NR SR. ${ }^{39}$ Prezidentovi d’alej patrí (4) prijímanie demisie vlády resp. jej členov a najnovšie aj (5) poverovanie vlády vykonávaním jej pôsobností do vymenovania novej vlády v prípade, ak jej NR SR vyslovila nedôveru alebo zamietla jej žiadost' o vyslovenie dôvery. Ústava SR prezidentovi výslovne zveruje aj (6) právo vyžadovat' si od vlády a od jej členov informácie potrebné na plnenie jeho úloh.

Podobne ako v prípade právomocí prezidenta smerujúcich $\mathrm{k}$ NR SR, aj jeho právomoci vo vzt’ahu k vláde sa počas ústavného vývoja dočkali viacerých dôležitých zmien. V centre pozornosti, prakticky už od vzniku SR, bola právomoc vymenúvat' a odvo-

\footnotetext{
36 Viac k vývoju právomocí prezidenta SR vo vzt’ahu k NR SR napr. v CIBULKA, L': Vývoj prezidenta v ústavnom systéme Slovenskej republiky (v kontexte zmien Ústavy Slovenskej republiky). Actas Facultatis Iuridicae Universitatis Comenianae, 2012, roč. 31, č. 1, s. 101 a nasl.

37 Porovnaj čl. 113 Ústavy SR.

38 Porovnaj čl. 108 Ústavy SR.

39 Porovnaj čl. 115 ods. 1 Ústavy SR.
} 
lávat' predsedu vlády a na jeho návrh aj d’alších členov vlády. Ústava SR vo svojom pôvodnom znení ustanovovala, že prezident „vymenúva a odvoláva“ predsedu vlády a ostatných členov vlády. ${ }^{40}$ Už v r. 1993 však politická prax ukázala nejasnost’ citovanej formulácie, kedy prezident nevyhovel návrhu predsedu vlády na vymenovanie nového člena vlády potom, ako vyhovel návrh na odvolanie iného člena vlády. Vznikol teda spor, či oprávnenie prezidenta vymenúvat' a odvolávat' člena vlády na návrh predsedu vlády znamená ústavnú povinnost' prezidenta návrhu predsedu vlády vyhoviet' alebo či prezident má možnost' návrhu aj nevyhoviet'. Ústavný súd vo svojom výkladovom rozhodnutí uviedol, že ,,podaním návrhu predsedu vlády Slovenskej republiky na odvolanie člena vlády vzniká prezidentovi Slovenskej republiky právna povinnost' návrhom sa zaoberat". Súčasne dodal, že prezident nemá povinnost' návrhu predsedu vlády vyhoviet'. Na uvedené rozhodnutie Ústavného súdu reagoval ústavodarca, ked' prostredníctvom ústavného zákona č. 9/1999 Z. z. slovné spojenie „vymenúva a odvoláva“ v čl. 111 Ústavy SR nahradil slovným spojením ,vymenuje a odvolä“. Zostáva však otázne, či vyššie uvedenou zmenou slovného spojenia sa problém skutočne odstránil. ${ }^{41}$

Ďalšou dôležitou zmenou v rámci prezidentských právomocí smerujúcich voči vláde bolo aj „odobratie“ možnosti prezidenta byt' prítomný na schôdzach vlády a dokonca týmto schôdzam predsedat'. Túto právomoc prezidentovi zverovalo pôvodné znenie Ústavy SR. ${ }^{42} \mathrm{Za}$ akýsi „zbytok“ tejto právomoci, ktorá svojou povahou koncepčne nezapadala do prostredia parlamentnej formy vlády, možno považovat' súčasnú právomoc prezidenta požadovat' od vlády a jej členov informácie potrebné pre výkon jeho funkcie. Toto právo prezidenta súvisí, okrem iného, aj so všeobecnou ústavnou povinnost'ou štátnych orgánov vzájomne spolupracovat'.

Osobitné miesto spomedzi tých noviel Ústavy SR, ktoré sa dotkli právomocí prezidenta SR, má nepochybne novela realizovaná ústavným zákonom č. 356/2011 Z. z, ${ }^{43}$ ktorá výrazným spôsobom zasiahla do architektúry vzt’ahov vyplývajúcich z formy vlády uplatňujúcej sa v SR a výrazne posilnila ústavné postavenie prezidenta SR. Slovenská republika, ako sme už konštatovali, vychádza z princípov parlamentnej formy vlády. Ústavným orgánom s rozhodujúcim vplyvom na celú formu vlády je teda NR SR ako najvyšší zastupitel'ský orgán, legitimizovaný prostredníctvom všeobecných volieb.

Prijatie ústavného zákona č. 356/2011 Z. z. novelizujúceho Ústavu SR bolo dôsledkom politickej krízy, ktorá nastala po neschválení tzv. Eurovalu, ${ }^{44} \mathrm{~s}$ ktorým vláda SR

40 Porovnaj čl. 102 písm. f) a čl. 110 a 111 Ústavy SR v pôvodnom znení.

${ }^{41} \mathrm{~K}$ polemike o povinnosti prezidenta návrhu predsedu vlády vyhoviet' porovnaj napr. aj KOUDELKA, Z.: Vztah prezidenta a vlády v oblasti jmenování. In: ŠIMÍČEK, V. (ed.): Postaveni prezidenta v ústavním systému České republiky. Brno: Masarykova univerzita, Mezinárodní politologický ústav, 2008, s. 169 a nasl.; KOUDELKA, Z.: Vztah prezidenta a vlády v oblasti jmenovaní. In: OROSZ, L. - DOBROVIČOVÁ, G. (eds.): 15 rokov Ústavy Slovenskej republiky. Košice: Právnická fakulta UPJŠ a Košický samosprávny kraj, 2008, s. 351 a nasl. či WINTR, J.: Prezident republiky jako reprezentant státu, garant řádu a moderátor politických sporů. In: ŠIMÍČEK, V. (ed.): Postaveni prezidenta v ústavním systému České republiky. Brno: Masarykova univerzita, Mezinárodní politologický ústav, 2008, s. 32.

42 Porovnaj čl. 102 písm. p) a r) Ústavy SR v pôvodnom znení.

43 Ústavný zákon č. 356/2011 Z. z., ktorým sa doplńa Ústava Slovenskej republiky č. 460/1992 Zb. v znení neskorších predpisov.

44 Išlo o dodatok k rámcovej zmluve uzatvorenej medzi členskými štátmi Európskej únie a Európskym finančným stabilizačným nástrojom. 
v zmysle čl. 114 ods. 3 Ústavy SR spojila hlasovanie o dôvere vláde. Národná rada však vláde dôveru nevyslovila, čím vznikla prezidentovi v zmysle čl. 115 Ústavy SR povinnost' vládu odvolat'. Aby toho nebolo málo, k vzniknutej politickej kríze prispel aj pre politickú sút’až neštandardný stav, kedy žiadna z parlamentných politických síl nemala záujem na vytvorení novej vlády. Existujúce znenie čl. 115 ods. 1 Ústavy SR, ktoré malo byt' aplikovatel'né na prípad nevyslovenia dôvery vláde zo strany NR SR, tak za daných okolností vyvolalo dva problémy. Prvý problém spočíval v tom, že pre prezidenta nevyplývala lehota, v ktorej má vládu odvolat'. Vážnejší bol druhý problém, pretože z dikcie tohto článku, na rozdiel napr. od článku 115 ods. 2 Ústavy SR, ${ }^{45}$ jednoznačne nevyplýval d'alší postup prezidenta po odvolaní vlády. Z doslovného výkladu článku 115 ods. 1 Ústavy SR nevyplývalo oprávnenie prezidenta poverit' vládu, ktorej nebola vyslovená dôvera, resp. ktorej bola žiadost' o vyslovenie dôvery zamietnutá, výkonom funkcie do vymenovania novej vlády. Interpretáciou celého tohto článku a súčasne ducha a obsahu celej ústavy vznikala pre prezidenta po odvolaní vlády z dôvodu nevyslovenia dôvery povinnost' súčasne vymenovat' novú vládu, pretože v opačnom prípade by nastalo ústavné vákuum. K takémuto kroku však absentovala ústavná úprava a parlamentné politické strany odmietli vytvorenie novej vlády. Vzhl'adom na uvedené východiská vznikla potreba riešit' spôsob zabezpečenia fungovania vlády ako vrcholného orgánu výkonnej moci, a to aj napriek tomu, že jej NR SR nevyslovila dôveru. Ústavný zákon č. 356/2011 Z. z., ktorý J. Drgonec označil za pravdepodobne najrýchlejšiu novelizáciu ústavy vôbec, ${ }^{46}$ doplnením čl. 102 ods. 1 o písm. u) a čl. 115 o ods. 3 expressis verbis udelil prezidentovi právomoc rozhodnút' o poverení vlády, ktorej NR SR nevyslovila dôveru, na výkon jej pôsobnosti až do vymenovania novej vlády, teda vlády, ktorá získa parlamentnú dôveru.

Ústavný zákon č. 356/2011 Z. z. nezakotvil len výslovnú možnost' prezidenta poverit' vládu bez dôvery NR SR vládnutím, aj ked' a priori dočasným, ale súčasne zakotvil aj to, že takáto vláda bude mat' obmedzený rozsah ústavných právomocí a taktiež aj to, že na výkon niektorých z nich bude potrebovat' predchádzajúci súhlas prezidenta. Otázne je predovšetkým to, či takáto úprava zásadným spôsobom nevybočuje z rámca parlamentnej formy vlády. Absurdne pritom pôsobí skutočnost', že výkon niektorých právomoci prezidenta je podmienený kontrasignáciu člena vlády. Prezident a vláda (bez dôvery NR SR) si tak svojim súhlasom navzájom podmieňujú výkon niektorých svojich ústavných právomocí. Ďalší problém, ktorý ústavný zákon č. 356/2011 Z. z. svojou nedôslednost'ou spôsobil, je ten, že v Ústave SR absentuje prechod právomoci poverit' vládu bez dôvery výkonom jej pôsobností na iný ústavný orgán, a to pre prípad nutnosti zastupovania prezidenta. ${ }^{47}$

45 Ustanovenie čl. 115 ods. 2 Ústavy SR upravovalo postup po demisii vlády.

46 Porovnaj DRGONEC, J.: Ústava Slovenskej republiky. Komentár. Šamorín: Heuréka, 2012, s. 1173.

47 Pre podrobnejšiu analýzu nevyhnutnosti prijatia ústavného zákona č. 356/2011 Z. z., ako aj pre podrobnejšiu analýzu jeho dôsledkov, pozri napr. CIBULKA, L'.: Vývoj prezidenta v ústavnom systéme Slovenskej republiky (v kontexte zmien Ústavy Slovenskej republiky). Actas Facultatis Iuridicae Universitatis Comenianae, 2012, roč. 31 , č. 1 , s. 110 a nasl. 
Ad 4)

Prezidentovi Ústava SR zveruje aj dôležité právomoci vo vzt’ahu k súdnej moci. Tie možno vo všeobecnosti rozdelit’ na dve skupiny. Prvú z nich tvoria kreačné právomoci, druhú právomoci, ktorými prezident zasahuje priamo do výsledkov výkonu súdnej moci. Pokial' ide o kreačné právomoci, prezident sa podiel'a na personálnom obsadzovaní tak všeobecných súdov, ÚS SR, ako aj Súdnej rady SR. Prezidentovi v kreačnej oblasti patria nasledujúce právomoci: (1) vymenúvanie a odvolávanie sudcov všeobecných súdov, a to na návrh Súdnej rady SR; (2) vymenúvanie a odvolávanie predsedu Najvyššieho súdu SR; (3) vymenúvanie a odvolávanie sudcov ÚS SR, a to z dvojnásobného počtu kandidátov zvolených v NR SR a (4) vymenúvanie a odvolávanie predsedu a podpredsedu ÚS SR. Vo vzt'ahu k Súdnej rade SR, ktorá predstavuje predovšetkým orgán sudcovskej legitimity, prezidentovi patrí (5) právomoc vymenúvat' a odvolávat' troch jej členov.

Druhú skupinu prezidentských právomocí vo vzt’ahu k súdnej moci tvoria tie právomoci, ktoré prezidentovi umožňujú priamo zasahovat' do výsledkov výkonu súdnej moci. Ústava SR v rámci tejto kategórie predpokladá právomoc (1) odpúšt'at' a zmierňovat' tresty uložené súdmi v trestnom konaní, ako aj (2) zahladzovanie takýchto odsúdení. $\mathrm{V}$ oboch prípadoch prichádza do úvahy forma individuálnej milosti alebo amnestie. Aj popísané právomoci prezidenta zasahujúce do výsledkov výkonu súdnej moci prešli nezanedbatel'ným vývojom. Pôvodná ústavná úprava totiž prezidentovi zverovala aj právomoc nariadit', aby sa trestné stíhanie ani nezačínalo a pokial' sa už začalo, aby sa v ňom d'alej nepokračovalo. ${ }^{48}$ Išlo teda o právomoc tzv. abolície. V dôsledku negatívnych skúseností s realizáciou aboličnej právomoci v rámci tzv. Mečiarových amnestií ${ }^{49}$ však napokon túto právomoc prezidentovi vzal ústavný zákon č. 90/2001 Z. z. Ešte takmer ,horúcou“ novinkou je aj možnost’ Národnej rady rozhodnutie prezidenta, ktorým udelil individuálnu milost’ alebo amnestiu, svojim uznesením zrušit'. ${ }^{50}$

Ad 5 a 6 )

Ústava SR zveruje prezidentovi aj d’alšie kreačné právomoci. Okrem kreačných právomocí, ktorými sa podiel'a na kreovaní vlády a orgánov súdnej moci, prezidentovi patri aj nasledujúce kreačné právomoci: (1) vymenúvanie a odvolávanie generálneho prokurátora SR, a to na návrh NR SR; (2) vymenúvanie a odvolávanie vedúcich ústredných orgánov, vyšších štátnych funkcionárov a d'alších funkcionárov v prípadoch, ktoré ustanoví zákon; (3) vymenúvanie a odvolávanie rektorov vysokých škôl a (4) vymenúvanie vysokoškolských profesorov.

A napokon, prezidentovi Ústava SR zveruje aj právomoc udel'ovat' vyznamenania, pokial' na to nesplnomocní iný orgán. Túto právomoc možno označit’ ako tradičnú prerogatívu hlavy štátu. ${ }^{51}$

48 Porovnaj čl. 102 písm. i) Ústavy SR v pôvodnom znení.

49 Išlo o dve rozhodnutia predsedu SR o udelení amnestie, ktorý v tom čase vykonával prezidentské právomoci. Konkrétne išlo o rozhodnutia č. 55/1998 Z. z. a č. 214/1998 Z. z.

50 Porovnaj čl. 88a Ústavy SR, ktorý bol doplnení ústavný zákonom č. 71/2017 Z. z., ktorým sa mení a dopĺna Ústava Slovenskej republiky č. 460/1992 Zb. v znení neskorších predpisov.

51 V súvislosti s touto ústavnou právomocou prezidenta je do určitej miery problematický zákon č. 261/2017 Z. z. o štátnej cene Jozefa Miloslava Hurbana a štátnej cene Alexandra Dubčeka, ktorý udel'ovanie po- 
Pokial ide o stručnú komparáciu vývoja právomocí prezidenta SR s právomocami, ktoré zverovala prezidentovi Ústavná listina ČSR, je možné konštatovat', že právomoci oboch hláv štátov boli podobné. Osobitne to platí o prvej z nami spomenutých skupín, čiže o právomociach vo vzt'ahu k zahraničiu a bezpečnosti štátu (napr. zastupovanie štátu navonok, dojednávanie a ratifikácia medzinárodných zmlúv či prijímanie a poverovanie vyslancov). Výraznú podobnost' je však možné hl'adat' aj v ostatných oblastiach (právo suspenzívneho veta, podávanie správ o stave republiky či vymenúvanie vysokoškolských profesorov). Črtou ústavnej úpravy právomocí prezidenta ČSR však je, na rozdiel od ústavnej úpravy v prípade jeho slovenského „nástupcu“, výraznejšia obsahová stručnost'. Táto stručnost' sa týka, okrem iného, najmä kreačných právomocí prezidenta vo vzt'ahu $\mathrm{k}$ vláde. $Z$ obsahového hl'adiska sú však aj tieto právomoci vel’mi podobné. Podobnost' sa dokonca týka aj právomoci, ktorú sme označili za nie práve typickú pre ústavné systémy vychádzajúce z parlamentnej formy vlády, teda právomoci prezidenta zúčastňovat' sa na zasadnutiach vlády a predsedat’ im. Aj v prostredí Československej republiky však túto právomoc možno hodnotit’ rozporuplne. Ako uvádza napr. F. Weyr, ide pravdepodobne o pozostatok tzv. korunných rád z monarchistických čias. Rovnaký autor navyše dodáva, že účast' a predsedanie prezidenta na zasadnutiach vlády sa ani počas existencie Československej republiky nestala pravidlom. ${ }^{52} \mathrm{~V}$ tejto otázke však, ako sme už uviedli vyššie, došlo počas formovania ústavného postavenia prezidenta SR k vzdialeniu sa od pôvodného československého modelu, nakol'ko jedna z noviel Ústavy SR prezidentovi túto právomoc odobrala.

\section{SPÔSOB VÝKONU PRÁVOMOCÍ PREZIDENTA}

Ústavné postavenie hlavy štátu neformuluje len rozsah a povaha právomocí, ktoré jej ústava zveruje. Nezanedbatel’ný vplyv na celkové postavenie hlavy štátu má aj spôsob ich výkonu. To, akým spôsobom má hlava štátu svoje právomoci vykonávat' z nej môže v konečnom dôsledku urobit' len ceremoniálnu hlavu štátu, avšak, na druhej strane, opačným dôsledkom môže byt' aj jej silné mocenské postavenie. V plnej miere to platí aj v prípade prezidenta SR.

Právomoci hlavy štátu, vrátane právomocí prezidenta SR, môžeme so zretel’om na spôsob ich výkonu rozdelit’ na autonómne právomoci a viazané právomoci. Za autonómne právomoci môžeme označit' tie právomoci, ktoré môže hlava štátu vykonávat' sama bez nevyhnutnej súčinnosti s iným ústavným orgánom. Naopak, viazanými právomocami sú tie právomoci, ktoré hlava štátu môže vykonávat' len v súčinnosti s inými ústavnými orgánmi. Táto súčinnost' pritom môže mat' rôznu podobu. Môže íst' napr. o nevyhnutnost' predchádzajúceho návrh, bez ktorého hlava štátu svoju právomoc realizovat' nemôže (ex ante súčinnost') alebo môže íst' o inštitút kontrasignácie, ktorým sa realizácia právomoci hlavy štátu následne potvrdzuje (ex post súčinnost'). Sú to práve

dobných ocenení, akými sú štátne vyznamenania, zveril predsedovi NR SR a vláde SR. Ústavnost’ tohto zákona bola napokon napadnutá aj na ÚS SR. Predmetné konanie je vedené pod sp. zn. PL. ÚS 4/2018 a v čase odovzdania rukopisu (začiatok mája 2018) nebolo zatial' vo veci meritórne rozhodnuté.

52 Porovnaj WEYR, F.: Československé právo ústavní. Praha: Melantrich, 1937, s. 204. 
viazané (menovacie resp. kreačné) právomoci, ktoré prezident môže realizovat' len na návrh, ktoré v praktickom fungovaní ústavného systému SR, pokial' ide o miesto prezidenta v ňom, spôsobujú najväčšie t’ažkosti.

Pokial' ide o vývoj spôsobu výkonu právomocí prezidenta SR, možno pozorovat' dve základné línie. Jednou vývojovou líniou sú novelizácie pôvodného textu Ústavy SR ústavnými zákonmi, druhou je rozhodovacia činnost' ÚS SR.

Ústavným zákonom, ktorý výraznejším spôsobom zmenil spôsob výkonu prezidentských právomoci, bol ústavný zákon č. 9/1999 Z. z. Tento ústavný zákon zakotvil, a d’alšia novela Ústavy SR, t. j. ústavný zákon č. 90/2001 Z. z. precizovala, tzv. inštitút kontrasignácie aktov hlavy štátu. Ide o inštitút tradične spájaný s ústavnými systémami vychádzajúcimi z parlamentnej formy vlády. V podobe, v akej bol zavedený do ústavného systému SR predstavuje nevyhnutnost' spolupodpísania (kontrasignácie) vybraných rozhodnutí prezidenta bud' predsedom vlády alebo predsedom vlády povereným ministrom. ${ }^{53}$ Dôsledkom kontrasignácie rozhodnutia prezidenta je jednak platnost' dotknutého rozhodnutia, ako aj Ústavou SR výslovne konštatovaný prechod zodpovednosti za takéto rozhodnutie prezidenta na vládu. Pokial' ide o vecný rozsah inštitútu kontrasignácie, Ústava SR kontrasignáciu zaviedla len vo vel'mi úzkom rozsahu, čiže len vo vzt’ahu k niektorým právomociam prezidenta. Ide o nasledujúce právomoci: (1) prijímanie, poverovanie a odvolávanie vedúcich diplomatických misií; (2) odpúšt’anie a zmierňovanie trestov uložených súdmi v trestnom konaní a zahládzania odsúdení, avšak len vo forme amnestie a (3) hlavné velenie ozbrojeným silám. Takto zavedený inštitút kontrasignácie možno považovat' za riešenie, ktoré zostalo niekde na „pol ceste“. Zavedenie predmetného inštitútu do ústavného systému SR tak možno hodnotit' skôr ako riešenie formálne a ,propagačné", ktorým mal ústavodarca snahu o akési priblíženie postavenia prezidenta SR k postaveniu hlavy štátu v klasickej parlamentnej forme vlády, no bez všetkých s tým spojených dôsledkov. Vzhl’adom na uvedené sa javí de constitutione ferenda ako vhodné precizovat' spôsob výkonu prezidentských právomocí, a to bud' zaviest' inštitút kontrasignácie aj vo vztahu k d'alších právomociam prezidenta SR majúcim exekutívny charakter, alebo tento inštitút, ktorý je napr. vo svojej podstate len t’ažko zlučitel'ný s priamou vol'bou hlavy štátu občanmi, z ústavného systému úplne vypustit'. ${ }^{54}$

Ovel’a bohatší je vývoj spôsobu výkonu právomocí prezidenta SR realizovaný prostredníctvom rozhodovacej činnosti ÚS SR. Táto sa týka v podstate výlučne menovacích či kreačných právomocí prezidenta, pretože práve tieto právomoci sa v praktickom ústavnopolitickom živote ukázali ako problematické. To, do akej miery $\mathrm{k}$ tomu prispelo znenie textu Ústavy SR a do akej miery politická kultúra, je však už na samostatnú polemiku. ${ }^{55}$

53 Porovnaj čl. 102 ods. 2 Ústavy SR.

54 Viac k hodnoteniu inštitútu kontrasignácie aktov hlavy štátu v podmienkach ústavného systému SR napr. v DOMIN, M.: Inštitút kontrasignácie aktov hlavy štátu. Osobitne v podmienkach ústavného systému Slovenskej republiky. Bratislava: PraF UK, 2015, s. 125 a nasl.

55 Viac k problematike uplatňovania menovacích resp. kreačných právomocí prezidenta SR pozri napr. v CIBULKA, L'.: Kreačné právomoci prezidenta SR - koncepčné otázky ich uplatňovania? In: Proměny dělby moci: Délba moci v ústavním systému České republiky a Polské republiky. Olomouc: Iuridicum Olomoucense, 2015, s. 161-170; DRGONEC, J.: Menovacie právomoci prezidenta Slovenskej republiky (1.) In: Zo súdnej praxe, 2014, roč. 19, č. 1, s. 2-6; DRGONEC, J.: Menovacie právomoci prezidenta Slovenskej 
Prvé z rozhodnutí ÚS SR, ktoré prispeli k vývoju spôsobu výkonu právomoci prezidenta, sme už spomenuli v rámci predchádzajúcej časti. Išlo o uznesenie ÚS SR sp. zn. I. ÚS 39/93, ${ }^{56}$ ktorým Ústavný súd podal taký výklad relevantných ustanovení Ústavy SR, ${ }^{57} \mathrm{v}$ zmysle ktorého prezidentovi nevzniká povinnost' vyhoviet' návrhu predsedu vlády na odvolanie člena vlády. Povinnost'ou prezidenta je len sa predmetným návrhom zaoberat'. Ako sme však už konštatovali, ústavodarca v snahe o prekonanie tohto rozhodnutia ÚS SR reagoval novelou Ústavy SR a korekciou použitého slovného spojenia, aj ked' nie úplne dôsledným spôsobom.

Trend praktických sporov ohladom výkladu spôsobu výkonu kreačných právomocí prezidenta pokračoval aj po r. 1993. Ústavný súd vo svojom uznesení sp. zn. PL. ÚS $14 / 06^{58}$ podal výklad právomoci prezidenta vymenúvat' vedúcich ústredných orgánov. In concreto išlo o vymenúvanie viceguvernéra Národnej banky Slovenska. Ústavný súd dal v citovanom rozhodnutí za pravdu prezidentovi, ked' uviedol, že prezident návrhu na vymenovanie nevyhovie v prípade, pokial' navrhnutý kandidát nespĺña zákonné predpoklady pre výkon danej funkcie. Na toto rozhodnutie čiastočne ÚS SR nadviazal v r. 2012, kedy podal výklad právomoci prezidenta vymenúvat' generálneho prokurátora SR. V danom prípade vznikol spor medzi NR SR, ktorá $\mathrm{v}$ zmysle ústavných pravidiel zvolila kandidáta na funkciu generálneho prokurátora, a prezidentom, ktorý tohto kandidáta za generálneho prokurátora nevymenoval. Konečné rozhodnutie ÚS SR $\mathrm{v}$ tejto veci vyvolalo značné kontroverzie, o čom svedčí aj viacero odlišných stanovísk jednotlivých sudcov ÚS SR. Ústavný súd v uznesení sp. zn. PL. ÚS 4/201259 priznal prezidentovi možnost' nevymenovat' generálneho prokurátora nie len z dôvodu nesplnenia zákonných predpokladov na nevymenovanie, ale aj z d’alšieho, pomerne vágne formulovaného dôvodu. Týmto dôvodom môže byt' závažná skutočnost' vzt'ahujúca sa na osobu kandidáta na funkciu generálneho prokurátora, ktorá dôvodne spochybňuje jeho schopnost' vykonávat' funkciu spôsobom neznižujúcim vážnost' danej ústavnej funkcie, resp. spôsobom, ktorý by bol v rozpore s poslaním prokuratúry.

A napokon, najaktuálnejším problémom je otázka spôsobu, akým má prezident vykonávat' svoju právomoc vymenúvat' sudcov ÚS SR. Klúčcvou je otázka, či prezident má povinnost' z dvojnásobného počtu kandidátov, ktorých mu predkladá NR SR, vždy polovicu z nich vymenovat'. Koreňom sporu bol postup prezidenta, ktorý v r. 2014 zo šiestich kandidátov, ktorých mu na tri uvol'není miesta sudcov ÚS SR zvolila Národná rada, vymenoval len jedného. Opieral sa pritom o všeobecné závery rozhodnutia ÚS SR, ktoré bolo vydané vo veci generálneho prokurátora. Návrh na výklad relevantných ustanovení Ústavy SR Ústavný súd $\mathrm{v}$ tejto veci meritórne prejednat' odmietol, a to z dôvodu, že vec, podl’a názoru väčšiny pléna ÚS SR, už nebola sporná. Ústavný súd v tomto uznesení, sp. zn. PL. ÚS 45/2015, ${ }^{60}$ odkázal na nález III. ÚS 571/2014, ${ }^{61}$ kto-

republiky (2.) In: Zo súdnej praxe, 2014, roč. 19, č. 2, s. 53-58 alebo MAJERČÁK, T.: Kreačné právomoci prezidenta Slovenskej republiky. Justičná revue, 2012, roč. 64, č. 10, s. 1148-1164.

56 Uznesenie ÚS SR z 2. júna 1993, sp. zn. I. ÚS 39/93.

57 Išlo o čl. 116 ods. 4 Ústavy SR.

58 Uznesenie ÚS SR z 23. septembra 2009, sp. zn. PL. ÚS 14/06.

59 Uznesenie ÚS SR z 24. októbra 2012, sp. zn. PL. ÚS 4/2012.

${ }^{60}$ Uznesenie ÚS SR z 28. októbra 2015, sp. zn. PL. ÚS 45/2015.

61 Nález ÚS SR zo 17. marca 2015, sp. zn. III. ÚS 571/2014. 
rým jeden zo senátov Ústavného súdu rozhodol o porušení základných práv kandidátov na sudcov ÚS SR tým, že ich prezident SR odmietol vymenovat'. Celý spor vyvrcholil nálezom ÚS SR zo 6. decembra 2017, sp. zn. I. ÚS 575/2016, ktorým aj d’alší senát rozhodol o tom, že prezident svojimi rozhodnutiami o nevymenovaní kandidátov na sudcov ÚS SR porušil ich základné práva. Ústavný súd súčasne týmto rozhodnutím opät zrušil sporné rozhodnutia prezidenta a expressis verbis prezidentovi prikázal, aby vo veci znova konal a rozhodol tak, že z dostatočne zvoleného počtu kandidátov navrhnutých Národnou radou vymenoval troch za sudcov ÚS SR. Prezident napokon rozhodnutie ÚS SR rešpektoval a na zostávajúce vol'né miesta sudcov ÚS SR vymenoval.

Pokial' ide o komparáciu so spôsobom výkonu právomocí prezidenta ČSR, ten nebol zásadným spôsobom ovplyvnený rozhodovacou činnost'ou vtedajšieho ústavného súdu. Súviselo to jednak so skutočnost'ou, že Ústavný súd ČSR prakticky fungoval len desat' rokov, avšak predovšetkým so skutočnost'ou, že prvý ústavný súd na našom území nemal právomoc podávat' výklad ústavy ako samostatný výsledok konania. ${ }^{62}$ Naopak, pokial' ide o inštitút kontrasignácie aktov hlavy štátu, $v$ tomto prípade možno vidiet' čiastočné približovanie sa ústavného postavenia prezidenta SR prvorepublikovému modelu hlavy štátu. Avšak, ako sme už načrtli v úvode, rozsah kontrasignovaných právomocí prezidenta ČSR bol ovel’a väčší. Kontrasignácia zodpovedným ministrom bola nevyhnutným predpokladom platnosti všetkých prezidentových úkonov moci vládne alebo výkonnej. ${ }^{63} \mathrm{Aj}$ napriek tomu, že Ústavná listina ČSR z formálneho hladiska vyžadovala kontrasignáciu pri všetkých aktoch prezidenta týkajúcich sa výkonnej resp. vládnej moci, dobová ústavnoprávna literatúra takúto skutočnost' relativizovala. ${ }^{64}$

\section{ZODPOVEDNOSŤ PREZIDENTA}

V predchádzajúcich častiach sme sa venovali jednak právomociam prezidenta SR ako takým, ako aj spôsobu ich výkonu. Ústavné postavenie prezidenta však nie je ovplyvnené len tým, čo môže či nemôže prezident ako hlava štátu konat', ale nepochybne aj tým, či nesie za výkon svojej funkcie zodpovednost'.

Typickým znakom ústavných systémov vychádzajúcich z klasickej parlamentnej formy vlády bola nezodpovednost’ hlavy štátu za výkon svojej funkcie, spravidla s výnimkou zodpovednosti za porušenie ústavy či zodpovednosti za vlastizradu (velezradu). Nezodpovednost' hlavy štátu je neraz $\mathrm{v}$ ústave štátu aj expressis verbis vyjadrená. ${ }^{65}$ Ústava SR v pôvodnom znení výslovne nezakotvovala ani zodpovednost' a ani nezodpovednost' prezidenta. Výnimkou bola možnost' stíhat' prezidenta pre vlastizra-

62 Pre podrobnosti pozri napr. DRGONEC, J.: Ochrana ústavnosti Ústavným súdom Slovenskej republiky. Žilina: Eurokódex, 2010, s. 21 a nasl.

63 Porovnaj § 68 Ústavnej listiny ČSR.

64 Porovnaj napr. WEYR, F.: Československé právo ústavní. Praha: Melantrich, 1937, s. 185.

65 Porovnaj napr. čl. 54 ods. 3 Ústavy Českej republiky, v zmysle ktorého ,prezident republiky nie je za výkon svojej funkcie zodpovedny' “ alebo čl. 90 Ústavy Talianska, podl'a ktorého „,prezident republiky nie je zodpovedný za svoje konanie pri výkone prezidentských právomocí, s výnimkou prípadu velezrady alebo porušenia Ústavy". 
du. ${ }^{66}$ Avšak, Ústava SR vo svojom pôvodnom znení zakotvovala, že NR SR môže prezidenta odvolat', a to ak vyvíja činnost' smerujúcu proti zvrchovanosti a územnej celistvosti SR alebo činnost' smerujúcu k odstráneniu demokratického ústavného zriadenia. ${ }^{67}$ Návrh na odvolanie mohla podat' nadpolovičná väčšina všetkých poslancov a o odvolaní Národná rada rozhodovala ústavou väčšinou, t. j. hlasmi minimálne troch pätín všetkých poslancov. Najmä ústavná dikcia „činnost’ smerujúcu proti zvrchovanosti a územnej celistvosti Slovenskej republiky“ umožňovala vel'mi široký výklad obsahu dôvodov na odvolanie prezidenta a teda i na vyvodenie zodpovednosti za jeho konanie. Z uvedeného vyplýva, že Ústava SR vo svojom pôvodnom znení, aj napriek tomu, že to výslovne neformulovala, predpokladala zodpovednost' prezidenta, aj ked' len $\mathrm{v}$ obmedzenom rozsahu.

K zmene ústavnej úpravy zodpovednosti prezidenta SR došlo novelou Ústavy SR vykonanou už spomínaným ústavným zákonom č. 9/1999 Z. z. Túto zmenu však nemožno označit' za koncepčnú, nakol'ko zodpovednost' prezidenta zostala zachovaná. Došlo však k jej výraznej úprave, a to tak pokial' ide rozsah, ako aj pokial' ide o procesný postup jej vyvodenia.

Spomínaný ústavný zákon v nadväznosti na zmenu spôsobu vol'by prezidenta zakotvil nové znenie čl. 106 Ústavy SR. V citovanom článku stanovil, že prezidenta možno odvolat' z funkcie pred skončením volebného obdobia l’udovým hlasovaním o odvolaním prezidenta, ktoré môže byt' vyvolané výlučne uznesením NR SR prijatým hlasmi trojpätinovej väčšiny všetkých jej poslancov. Novoformulovaný čl. 106 Ústavy SR, na rozdiel od jeho pôvodného znenia, už žiadnym spôsobom neformuloval konanie prezidenta, ktoré môže viest' k jeho odvolaniu. Vzhl'adom na uvedené (prinajmenšom) od tohto okamihu môžeme zodpovednost' prezidenta zakotvenú v čl. 106 Ústavy SR shodnotit' ako formu ústavnopolitickej zodpovednosti. Súčasne však, s ciel'om zabránenia potenciálneho zneužívania inštitútu l'udového hlasovania o odvolaní prezidenta zo strany NR SR, Citovaný ústavný zákon zakotvil povinnost' prezidenta rozpustit' NR SR v prípade, ak by nebol v l’udovom hlasovaní odvolaný. ${ }^{68}$

Zakotvenie inštitútu l'udového hlasovania o odvolaní prezidenta však nebola jediná novinka, ktorú $\mathrm{v}$ oblasti ústavnopolitickej zodpovednosti ústavný zákon č. 9/1999 Z. z. priniesol. Ako sme uviedli už v predchádzajúcej časti príspevku, tento ústavný zákon zakotvil a d’alšia novela Ústavy SR, t. j. ústavný zákon č. 90/2001 Z. z. precizovala, tzv. inštitút kontrasignácie aktov hlavy štátu. Formálnym účinkom kontrasignácie je, ako už bolo uvedené, platnost' dotknutého rozhodnutia (aktu) prezidenta. V rámci výkladu o zodpovednosti prezidenta má však väčší význam materiálny účinok kontrasignácie. Dôsledkom kontrasignácie rozhodnutia prezidenta je totiž aj Ústavou SR výslovne konštatovaný prechod zodpovednosti za takéto rozhodnutie prezidenta na vládu SR. Aj napriek skutočnosti, že v odbornej literatúre nepanuje úplná zhoda nad povahou zodpovednosti za kontrasignované akty hlavy štátu, možno sa priklonit' k tvrdeniu, že vláda preberá ústavnopolitickú zodpovednost' za kontrasigno-

66 Porovnaj čl. 107 Ústavy SR v pôvodnom znení.

67 Porovnaj čl. 106 Ústavy SR v pôvodnom znení.

68 Prezident nie je v l'udovom hlasovaní odvolaný v prípade, pokial' za jeho odvolanie nahlasovala nadpolovičná väčšina všetkých oprávnených voličov. Porovnaj čl. 106 ods. 2 Ústavy SR. 
vané rozhodnutia prezidenta. ${ }^{69}$ Dôsledkom takejto zodpovednosti následne môže byt', v krajnom prípade, aj vyslovenie nedôvery vláde zo strany NR SR.

Ústavný zákon č. 9/1999 Z. z. priniesol zmeny aj v otázke ústavnoprávnej zodpovednosti prezidenta, teda jeho zodpovednosti, ktorú môže sankcionovat' ÚS SR. Podl'a novoformulovaného čl. 107 Ústavy SR možno prezidenta stíhat' za dva druhy skutkov, a to za vlastizradu a za úmyselné porušenie ústavy. ${ }^{70}$ Obžalobu podáva NR SR trojpätinovou väčšinou hlasov všetkých jej poslancov. Úlohu súdneho orgánu vykonáva ÚS SR. Ústavný súd rozhoduje rozsudkom a odsudzujúce rozhodnutie znamená jednak stratu funkcie prezidenta, ako aj ineligibilitu odsúdenej osoby. Pokial' ide o kvalifikáciu skutku, Ústava SR to, čo je potrebné považovat' za vlastizradu, nevymedzuje. Vykonávací predpis, čiže zákon o Ústavnom súde, ${ }^{71}$ výslovne ustanovuje, že na právnu kvalifikáciu skutku vlastizrady je ÚS SR viazaný Trestným zákonom. Pre samotné konanie pred Ústavným súdom sa majú primerane použit' ustanovenia procesného predpisu, ktorým je v tomto prípade Trestný poriadok..$^{72}$ Zo súčasného znenia čl. 107 Ústavy SR je možné d'alej vyvodit' aj to, že prezident nie je počas výkonu svojej funkcie trestnoprávne a ani administratívnoprávne zodpovedný, s výnimkou zodpovednosti za spáchanie priestupku, v prípade ktorého je však situácia zložitejšia. Novela zákona o priestupkoch síce v r. 2012 výslovne zaviedla zodpovednost' prezidenta za priestupky, no takáto úprava by mohla byt' v rozpore s čl. 107 Ústavy. ${ }^{73}$ Občianskoprávna zodpovednost' prezidenta SR však ústavnou úpravou nie je dotknutá. ${ }^{74}$

Ak stručne popísaný vývoj otázky zodpovednosti prezidenta SR porovnáme s prezidentom ČSR, je v prvom rade potrebné oddelit’ ústavnopolitickú a ústavnoprávnu zodpovednost'. Pokial' ide o ústavnopolitickú zodpovednost', v tomto prípade možno konštatovat', že postavenie prezidenta SR bolo zásadné odlišné tak podl'a pôvodného znenia Ústavy SR, ako aj po jej neskoršej novelizácii. Prezident ČSR totiž v zmysle $\S 66$ Ústavnej listiny ČSR expressis verbis nebol za výkon svojho úradu zodpovedný. ${ }^{75}$ Túto, pre parlamentné formy vlády klasickú ústavnopolitickú nezodpovednost' podčiarkovala aj ústavná požiadavka na kontrasignáciu všetkých prezidentových úkonov moci vládnej a výkonnej členom vlády, ktorý následne aj za prejavy prezidenta súvisiace s výkonom jeho úradu zodpovedal. Prvorepubliková ústavná úprava taktiež nepoznala inštitút, ktorý by umožňoval prezidenta $\mathrm{z}$ funkcie odvolat'. Pokial' ide o ústavnoprávnu zodpovednost', $v$ tejto otázke je si postavenie oboch hláv štátu bližšie. Zásadným roz-

69 Viac k podobe zodpovednosti za kontrasignované akty hlavy štátu pozri napr. v DOMIN, M.: Zodpovednost' za kontrasignované rozhodnutia prezidenta Slovenskej republiky. Justičná revue, 2013, roč. 65, č. 4, s. $443-463$.

$70 \mathrm{~K}$ zodpovednosti prezidenta SR za vlastizradu a úmyselné porušenie ústavy pozri napr. aj DRGONEC, J.: Obžaloba na prezidenta SR vo svetle prvej skúsenosti. Justičná revue, 2013, roč. 65, č. 6-7, s. 908-924.

71 Zákon Národnej rady Slovenskej republiky č. 38/1993 Z. z. o organizácii Ústavného súdu Slovenskej republiky, o konaní pred ním a o postavení jeho sudcov v znení neskorších predpisov.

72 Porovnaj § 74 zákona o Ústavnom súde.

73 Viac ku vzt’ahu zákonnej úpravy priestupkového práva a čl. 107 Ústavy napr. v DOMIN, M.: Zrušenie priestupkovej imunity a prezident Slovenskej republiky. Justičná revue, 2012, roč. 64, č. 4, s. 531-541.

74 Porovnaj napr. DRGONEC, J.: Ústava Slovenskej republiky. Teória a prax. Bratislava: C. H. Beck, 2015, S. 1250.

75 Politickú nezodpovednost' prezidenta ČSR však výrazne relativizoval napr. F. Weyr. Pre podrobnosti pozri napr. WEYR, F.: Československé právo ústavní. Praha: Melantrich, 1937, s. 186. 
dielom je len to, že Ústava SR po jej novelizácii rozšírila ústavnoprávnu zodpovednost’ hlavy štátu aj za úmyselné porušenie ústavy, zatial' čo Ústavná listina ČSR poznala len zodpovednost' za velezradu. ${ }^{76}$ Ďalšia odlišnost' sa týkala orgánu, ktorý v procese stíhania prezidenta predstavoval súdny orgán. V podmienkach ČSR ním bol Senát, čiže horná parlamentná komora.

\section{ZASTUPOVANIE PREZIDENTA}

Ústavné postavenie hlavy štátu nepochybne dotvára aj ústavná úprava jej zastupovania. V prípade prezidenta ako individuálnej hlavy štátu totiž prípadná absencia osoby, ktorá túto funkciu vykonáva, môže, na rozdiel od kolektívnych orgánov akými sú parlament alebo vláda, spôsobit' nezanedbatel'né poruchy v chode ústavného systému.

Aj vzhl'adom na uvedenú skutočnost' Ústava SR inštitút zastupovania prezidenta SR poznala už vo svojom pôvodnom znení. Zastupovanie prezidenta bolo a je založené na koncepcii, že v prípade, ak nastane Ústavou SR predpokladaná potreba zastupovania prezidenta, jeho vybrané právomoci ex constitutione a ipso facto prejdú na iný ústavný orgán. Pôvodne týmto orgánom bola len vláda SR, resp. jej predseda. Dôvody, ktoré takpovediac „aktivizujú“ zastupovanie prezidenta SR, zostali rovnaké do dnes. Ide o prípad, (1) ak prezident nie je zvolený; (2) ak sa úrad prezidenta uvol'nil a ešte nie je zvolený nový prezident; (3) ak nový prezident síce zvolený bol, no ešte nezložil sl’ub a o prípad, (4) ak prezident nemôže svoju funkciu vykonávat' pre závažné dôvody. Problematika prechodu konkrétnych právomocí prezidenta je však rovnako poznamenaná „hladaním“. Článok 105, ktorý tento inštitút vždy upravoval, patrí k azda najčastejšie novelizovaným ustanoveniam Ústavy SR. V procese realizácie pôvodného textu Ústavy SR sa totiž ukázalo, že v čase, kedy potreba zastupovania prezidenta SR v praxi skutočne vznikla, neprešli jeho viaceré významné právomoci na žiadny iný ústavný orgán, čo mohlo spôsobovat' vznik ústavných kríz.

Už prvé dve priame novelizácie Ústavy SR, a to ústavný zákon č. 244/1998 Z. z. a ústavný zákon č. 9/1999 Z. z. sa dotkli úpravy zastupovania prezidenta. Pôvodné znenie čl. 105 totiž nezakotvovalo prechod všetkých právomocí prezidenta na iný ústavný orgán. Na vládu SR ako celok prechádzali všetky prezidentské právomoci okrem právomoci rozpustit' NR SR, právomoci podpisovat' zákony, právomoci vymenúvat' a odvolávat' členov vlády a právomoci vymenúvat' a odvolávat' vedúcich ústredných orgánov a vyšších štátnych funkcionárov, ako aj profesorov a rektorov vysokých škôl a vymenúvat’ a povyšovat' generálov. Na osobu predsedu vlády prechádzala právomoc hlavného velenia ozbrojených síl. Na načrtnutý nedostatok, najmä absenciu zastupovania právomoci vymenúvat' vládu a rozpúštat' NR SR, reagoval ústavný zákon č. 244/1998 Z. z. Týmto ústavným zákonom sa ponechalo pravidlo, že na vládu prechádzajú všetky právomoci prezidenta až na niekol'ko výnimiek. Súčasne však zakotvil, že niektoré právomoci prechádzajú na predsedu NR SR. Išlo práve o vymenúvanie a odvolávanie predsedu a ostatných členov

76 Porovnaj § 67 Ústavnej listiny ČSR. 
vlády a právomoc vymenúvat’ a odvolávat' vedúcich ústredných orgánov a vyšších štátnych funkcionárov, ako aj profesorov a rektorov vysokých škôl. Zmeny v rozsahu zastupovania prezidentských právomocí zaznamenali aj dve d'alšie novely Ústavy SR, a to ústavný zákon č. 9/1999 Z. z. a ústavný zákon č. 90/2001 Z. z. Svojej ,zastupitel’nosti““ sa konečne dočkala predovšetkým právomoc rozpustit' NR SR, ktorá podl'a pôvodného textu Ústavy SR mala nezastupitel'ný charakter. Zmeny sa dočkala aj právomoc udel'ovat' milost' a amnestiu, ktorá sa, naopak, po negatívnych skúsenostiach s tzv. Mečiarovými amnestiami, stala nezastupitel'nou.

De constitutione lata je teda ústavný inštitút zastupovania prezidenta SR postavený na koncepcii, že v prípade, pokial' nastane niektorá z vyššie uvedených Ústavou SR predpokladaných skutočností, vybrané právomoci prechádzajú na vládu SR, na predsedu vlády SR a na predsedu NR SR. Niektoré právomoci však, ako sme už naznačili, neprechádzajú na žiadny iný ústavný orgán. V prípade právomoci rozhodovat' o odpustení trestu či o zahladení odsúdenia vo forme individuálnej milosti alebo amnestie nemožno hovorit' o probléme. Problémom však je opomenutie, ktoré sme už spomenuli pri výklade o právomociach prezidenta. Na žiadny ústavný orgán totiž podl'a platného znenia Ústavy SR neprechádza právomoc prezidenta poverit' vládu, ktorá stratila dôveru Národnej rady, d'alším výkonom jej pôsobností až do vymenovania novej vlády.

Osobitným dôvodom nie ani tak zastupovania ako skôr zbavenia funkcie prezidenta SR je neschopnost' túto funkciu vykonávat' po relatívne dlhé obdobie. Pôvodné znenie Ústavy SR zakotvovalo, že ak prezident nemôže svoju funkciu vykonávat' dlhšie ako jeden rok, NR SR ho z funkcie odvolá. ${ }^{77} \mathrm{~V}$ súvislosti so zmenou spôsobu vol'by prezidenta však ústavný zákon č. 9/1999 Z. z. právomoc NR SR nahradil právomocou Ústavného súdu. Lehotu však súčasne skrátil z jedného roka na šest' mesiacov. Ak teda prezident nemôže svoju funkciu vykonávat' dlhšie ako šest' mesiacov, ÚS SR vyhlási, že funkcia prezidenta sa uvol'nila.

Pokial' ide o komparáciu so zastupovaním prezidenta ČSR, možno konštatovat', že oba modely si spočiatku boli blízke, no vzájomné odlišnosti sa postupným vývojom ústavného postavenia prezidenta SR prehlbovali. V prípade, pokial' prezident ČSR nebol zvolený alebo bol zaneprázdnený alebo chorý, výkon jeho právomoci taktiež ex constitutione prechádzal na vládu. A rovnako ako v prípade SR, aj v prípade Československej republiky platilo, že vláda mohla poverit' svojho predsedu výkonom jednotlivých úkonov náležiacich do prezidentských právomocí. ${ }^{78}$ Podobnost' oboch modelov sa týka aj problematickej identifikácie toho, či nastali dôvody zastupovanie prezidenta. Ako uvádza F. Weyr, Ústavná listina ČSR nedávala odpoved' na to, ako zistit' či dôvody zastupovania nastali. ${ }^{79}$ To, v čom sa však československý model od toho slovenského líšil, bol inštitút námestníka prezidenta. Ten zastupoval prezidenta ČSR v prípade, pokial' bol prezident zaneprázdnený alebo chorý dlhšie ako šest' mesiacov. Kumulatívnou podmienkou bolo uznesenie vlády. Na základe takéhoto uznesenia vlády následne námestníka prezidenta ČSR zvolilo Národné zhromaždenie.

\footnotetext{
77 Porovnaj čl. 105 ods. 2 Ústavy SR v pôvodnom znení.

78 Porovnaj $\S 60$ Ústavnej listiny ČSR.

79 Porovnaj WEYR, F.: Ceskoslovenské právo ústavní. Praha: Melantrich, 1937, s. 209.
} 


\section{ZÁVER}

V príspevku sme sa snažili o stručné zhrnutie formovania ústavného postavenia prezidenta SR, a to na podklade vývoja ústavnej úpravy piatich vecných oblastí, ktoré vo svojom súhrne definujú ústavné postavenie každej hlavy štátu.

Na základe analýzy vývoja spôsobu ustanovovania prezidenta do jeho funkcie, jeho právomocí, osobitne spôsobu výkonu jeho právomocí, ako aj na základe analýzy vývoja zodpovednosti prezidenta a inštitútu jeho zastupovania možno konštatovat', že ústavné postavenie prezidenta SR de lege lata sa tomu pôvodnému výrazne vzdialilo. „Ubehnutác vzdialenost' síce nie je až taká, ktorá by nás oprávňovala hovorit’ napr. o tom, že prezident SR má $\mathrm{v}$ súčasnosti postavenie hlavy štátu ako v prezidentskej forme vlády, no súčasne nemožno tieto zmeny označit' ani za bezvýznamné. Za azda najzásadnejšiu možno označit' zmenu spočívajúcu v zavedení priamej vol'by prezidenta občanmi. Aj napriek pochybnostiam o dôvodoch, ktoré k tomu ústavodarcu viedli, možno súhlasit's názormi, a d’alší ústavný vývoj to aj potvrdil, že zavedenie priamej vol'by hlavy štátu bolo správne. ${ }^{80}$ Zavedenie priamej vol'by síce nebolo sprevádzané výrazným formálnym posilnením prezidentských právomocí, no k posilnení postavenia prezidenta nepochybne prispel ÚS SR, v prípade rozhodovacej činnosti ktorého možno identifikovat' trend posilňovania postavenia prezidenta, a to najmä jeho diskrécie pri výkone kreačných právomocí, azda s výnimkou riešenia sporu ohladom spôsobu výkonu jeho právomoci vymenúvat' sudcov tohto súdu. Pri konštatovaní posilnenia postavenia prezidenta nemožno zabúdat', samozrejme, ani na novelu Ústavy SR vykonanú ústavným zákonom č. 356/2011 Z. z., nech už jej obsah samotný hodnotíme akokol'vek. Záver o určitom posilnení postavenia prezidenta výrazne nenarúša ani zavedenie inštitútu kontrasignácie jeho rozhodnutí, a to predovšetkým so zretel'om na jeho „nedotiahnutie“ do komplexnejšej podoby. Náš záver zásadnejšie nenarúša ani formálne posilnenie zodpovednosti prezidenta, ktoré možno vidiet' vo vypustení konkrétnych skutkových podstát konaní, ktoré by mohli viest' k jeho odvolaniu. Vidina praktického využívania inštitútu l'udového hlasovania o odvolaní prezidenta je totiž viac ako nereálna.

Na úplný záver sme ešte dlžní zodpovedat' otázku položenú už v podnadpise tohto príspevku. Smerovalo doterajšie formovanie ústavného postavenia prezidenta SR skôr $\mathrm{k}$ prvorepublikovému prezidentskému modelu, alebo sa, naopak, od neho vzd'al'uje? Berúc do úvahy všetkých pät’ vecných oblastí, ktorým sme sa v príspevku venovali, dat' jednoznačnú a najmä jednoliatu odpoved' nie je jednoduché. Ak však zdôrazníme tú najzásadnejšiu zmenu v ústavnom postavení prezidenta SR, za ktorú sme označili zavedenie jeho priamej vol’by občanmi, vrátane na ňu nadväzujúcich zmien, či už re-

${ }^{80} \mathrm{~K}$ otázke výhod či nevýhod priamej vol’by hlavy štátu v širšom kontexte pozri napr. aj HLOUŠEK, V.: Př́ma volba prezidenta: český kontext. In: NOVÁK, M. - BRUNCLÍK, M. (eds.): Postavení hlavy státu $v$ parlamentnich a poloprezidentských režimech. Česká republika v komparativni perspektivě. Praha: Dokořán, 2008, s. 263-285; KUBÁT, M.: Přímá volba prezidenta v České republice? In: KYSELA, J. (ed.): Deset let Ústavy České republiky: Východiska, stav, perspektivy. Praha: Eurolex Bohemia, 2003, 299 a nasl. či ŠIMÍČEK, V.: Alternativa k navrhovaným spůsobům volby prezidenta. Politologický časopis, 2001 , roč. 8 , č. 4 , s. 388 a nasl. 
alizovaných alebo potenciálnych, možno sa skôr priklonit’ k odpovedi, že postavenie prezidenta SR sa svojmu, dnes už storočnému modelu, postupne vzd'al'uje.

prof. JUDr. L'ubor Cibulka, CSc.

Právnická fakulta UK v Bratislave

lubor.cibulka@flaw.uniba.sk

doc. JUDr. Marek Domin, Ph.D.

Právnická fakulta UK v Bratislave

marek.domin@flaw.uniba.sk 